\title{
NORA PASTERNAC: UNA ENTRAÑABLE ESPECIE EN PELIGRO DE EXTINCIÓN \\ Claudia Albarrán*
}

\section{Nora Rosenfeld Slobinsky —a quien} todos conocemos como Nora Pasternac porque hace muchos años adoptó el apellido de Marcelo, su marido- siempre ha sido una mujer exótica: una persona extravagante en su delicada sencillez y, a la vez, una especie rara, en peligro de extinción (como el saltamontes, la libélula o la catarina), cuyas características y habilidades ancestrales de supervivencia hacen casi imposible describirla de un teclazo.

La conocí hace poco más de 26 años, en la oficina de Luz Elena Gutiérrez de Velasco, entonces directora del antiguo Centro de Lenguas del ITAM (hoy Departamento Académico de Lenguas). Rodolfo Vázquez acababa de contratarme como profesora de medio tiempo para dar una clase de Problemas en el Departamento de Estudios Generales y para impartir un curso de Redacción en el Centro de Lenguas, en el que Nora llevaba trabajando poco tiempo.

Era enero de 1992. Estaba a punto de iniciar el semestre y Luz Elena me había citado en su oficina para explicarme cuáles serían las responsabilidades de mi nuevo trabajo. Yo esperaba en el pasillo, inquieta, con mi panza de ocho meses de embarazo (mi hija Ana nació un mes después), preguntándome todavía qué demonios haría para dar mis clases en dos departamentos y atender a mi recién nacida, cuando se abrió la puerta de la oficina de Luz Elena y me encontré por primera vez con Nora,

* Departamento Académico de Lenguas, ITAM. 
DOSSIER

que estaba sentada ahí dentro, con su pelo lacio, su sonrisa curiosa y ese porte elegante que siempre ha conservado.

Te presento a Nora Pasternac, me dijo Luz Elena. Y a partir de entonces comenzamos a trabajar juntas en la elaboración de los exámenes de Redacción que hacíamos en nuestras máquinas de escribir (en ese tiempo no había computadoras ni internet ni celulares) y en una larguísima lista de actividades académicas que nos han permitido convivir de muy variadas maneras: como madre e hija, como abuela y nieta, como vecinas cómodas y como colegas cercanas, pero también como hija y madre, como nieta y abuela, como vecinas incómodas, como colegas distantes y conductoras perdidas en el caótico tráfico del ITAM. Lo que quiero decir es que, gracias a todos estos papeles que ambas hemos venido intercambiando a lo largo de estos años, he podido conocer de cerca a una Nora multifacética, única en su personalidad y en su sabiduría, con sus alegrías, dolores, manías, pérdidas, sabores y sinsabores que, tras el recuento de los años vividos en el ITAM, han dado origen a una hermosa amistad, amasada a base de largas conversaciones, a pesar de que nunca he ido a su casa, de que no conocí al Señor González, su gato, ni tampoco he probado las delicias que Mari, su asistenta, le deja preparadas cuando ella vuelve cansada del ITAM.

Como el saltamontes, Nora ha realizado en su vida grandes migraciones: dejó su pequeño pueblo en Argentina para estudiar en la caótica Ciudad de México, y ha ido y venido de París a México y de México a París en innumerables ocasiones, tantas, que casi podría decirse que es una tercera parte argentina, otra tercera parte mexicana y una última parte francesa. En los treinta años que lleva en el ITAM, ha mudado de estatus académico varias veces: pasó de ser profesora de asignatura a ser profesora de medio tiempo y luego fue profesora de tiempo completo para volver a ser profesora de asignatura "plus", y volver a serlo de tiempo completo para retomar, en los últimos años, la asignatura "plus"; incluso fue jefa interina de nuestro Departamento en una o dos ocasiones. Hablamos de una sobreviviente de guerras y catástrofes, que la han llevado a desarrollar su capacidad de resistencia. Como el saltamontes - que si le falta comida, produce feromonas para fortalecer las alas y 
poder recorrer largas distancias - , Nora Pasternac tiene, entre sus virtudes, la de la adaptación a cualquier ambiente que la rodea, por hostil que sea. Si en su momento fue necesario que dejara la máquina de escribir y pasara a la computadora para eliminar de cuajo las erratas que siempre reaparecían en las infinitas trascripciones que hacíamos de los exámenes, no dudó ni un segundo en aprender a usarla. Cuando en el Departamento de Lenguas le pidieron que dejara los salones tradicionales e impartiera sus clases en aulas como la Shakespeare y la Cervantes, dotadas con sofisticada tecnología de punta, no dudó en dominarlas. Porque no hay nubarrón que Nora no pueda atravesar, ni montaña que no pueda escalar ni piedra que le impida el paso.

Como la libélula, quizá una de las maravillas más fascinantes que hay en la naturaleza, es un ser "escurridizo y feliz". En la libelulapedia se explica que este ser aparentemente frágil tiene la capacidad de reflejar una enorme gama de colores, dependiendo de los ángulos de la luz que reciban sus alas, y que se caracteriza por vivir al máximo cada momento de su vida, en especial durante su etapa adulta. Nora es así: un caleidoscopio que siempre irradia buena energía. Puedo constatar, pues, que, como los buenos vinos, la presencia de Nora en esta institución se disfruta mejor con el transcurrir de los años que ha llevado su añejamiento.

Y por último, Nora Pasternac es también una catarina: coqueta en su elegancia, alegre en su colorido, con sus antenas bien puestas, con sus dos pares de alas bien guardadas debajo del caparazón, aunque ella solo las use para volar si es absolutamente imprescindible. Se trata de una sorpresiva presencia roja que le pone chispa y humor a la vida cotidiana del ITAM, siempre lista para regalarnos consejos atinados (en los que también seguimos escuchando la voz de su difunto Marcelo, el gran amor de su vida) y frases que se han vuelto célebres entre los colegas del ITAM. Menciono solo una por ser, quizá, la más famosa: "Como dijo Jack El destripador, vayamos por partes".

Enhorabuena, querida Nora, por estos treinta años de trayectoria académica en el ITAM. Es un privilegio tenerte cerca. 